\title{
Studies on the Formation of Bacitracin by Bacillus licheniformis: Effect of Glucose
}

\author{
By H. I. HAAVIK \\ Department of Research and Development, A/S Apothekernes Laboratorium \\ for Specialpraparater, Oslo, Norway
}

(Received 29 August 1973; revised 8 November 1973)

SUMMARY

The production of bacitracin by Bacillus licheniformis closely paralleled growth in a synthetic medium without glucose: Glucose inhibited bacitracin production during the first hours of growth, whereas growth was not affected. Bacitracin was produced mainly during the later stages of growth. Formation of bacitracin was apparently not under catabolite repression control by glucose since the inhibitory effect of glucose upon the early bacitracin production was prevented by neutralizing the culture fluid with $\mathrm{CaCO}_{3}$. The inhibitory effect of glucose may be due to the low $\mathrm{pH}$ created by its metabolism.

Addition of $0.5 \%$ glucose markedly increased the maximum titre of bacitracin. This stimulation could also be due to the effect of glucose metabolism upon the $\mathrm{pH}$ of the medium. The observation that peptide antibiotics are produced mainly after growth is not always true; in appropriate media they might also be produced during the phase of rapid growth.

\section{INTRODUCTION}

Bacitracin is a peptide antibiotic produced by some strains of Bacillus licheniformis and B. subtilis (Anker, Johnson, Goldberg \& Meleney, 1948; Hickey, I964; Weinberg, 1967). Bernlohr \& Novelli (1960; 1963) have shown that it is produced after growth and before sporulation. They proposed that bacitracin is produced by the bacteria at this stage of their life cycle only.

Peptide antibiotics are frequently reported to be produced mainly after growth, e.g. penicillin, gramicidin $\mathrm{S}$, cephalosporin $\mathrm{C}$, tyrocidin, actinomycin, mycobacillin, edeine, polymyxins, triostin (Jarvis \& Johnson, 1947; Winnick, Lis \& Winnick, I96I; Demain, I963; Mach, Reich \& Tatum, I963; Katz, Wise \& Weissbach, r965; Banerjee, Majumdar \& Bose, 1967; Kurylo-Borowska, 1967; Paulus, 1967; Yoshida \& Katagiri, 1969).

It is generally believed that the producing organisms initiate the synthesis of peptide antibiotics towards the end of the exponential phase of growth. Consequently there has been much speculation about what function peptide antibiotics may play in the producer organisms at this stage of their life cycle (Katz, I968; 1971 ; Hurst, 1969; Sermonti, 1969; Hanson, Peterson \& Yousten, 1970; Hodgson, 1970; Weinberg, 1970; Jayaraman \& Kennan, 1972; Sadoff, 1972; Sarkar \& Paulus, 1972).

It has also been suggested that peptide antibiotics, like other secondary metabolites, are only produced by organisms that have recently stopped dividing (Bu'lock, I96I ; Woodruff, 1966; Weinberg, 1970; 1971).

Snoke (1960; I96I) reported that glucose markedly stimulated the synthesis of bacitracin by Bacillus licheniformis in defined medium. Glucose is a common constituent of media for 
antibiotic production and has also been reported to stimulate the production of mycobacillin, polymyxin A and actinomycin (Banerjee, Majumdar \& Bose, 1967; Paulus, 1967; Gallo \& Katz, 1972). No explanation of why antibiotic production is stimulated by glucose has been offered.

During a study of bacitracin production by Bacillus licheniformis in different synthetic media, both the kinetics of bacitracin formation and the maximum titre of bacitracin were greatly affected by the composition of the medium. The results obtained are described and discussed in this paper.

\section{METHODS}

Organisms. The bacitracin-producing strain Bacillus licheniformis ATCCI0716 was kept as a spore suspension at $4{ }^{\circ} \mathrm{C}$.

Media and growth conditions. The chemically defined medium (M2) for growth and bacitracin production had the following composition ( $\mathrm{g} / \mathrm{l}$ doubly distilled water): L-glutamic acid, 20.0; L-alanine, 0.2; citric acid, $\mathrm{I} \cdot 0 ; \mathrm{NaH}_{2} \mathrm{PO}_{4} .2 \mathrm{H}_{2} \mathrm{O}, 2.0 ; \mathrm{KCl}, 0.5 ; \mathrm{Na}_{2} \mathrm{SO}_{4}, 0.5$; $\mathrm{MgCl}_{2} .6 \mathrm{H}_{2} \mathrm{O}, 0.2 ; \mathrm{CaCl}_{2} .2 \mathrm{H}_{2} \mathrm{O}, 0.01 ; \mathrm{FeSO}_{4} \cdot 7 \mathrm{H}_{2} \mathrm{O}, 0.0 \mathrm{I} ; \mathrm{MnSO}_{4} . \mathrm{H}_{2} \mathrm{O}, 0.01$.

The $\mathrm{pH}$ was adjusted to $7 \cdot 0$ with $\mathrm{I} \mathrm{N}-\mathrm{NaOH}$ before autoclaving at $\mathrm{I} 2 \mathrm{I}{ }^{\circ} \mathrm{C}$ for $20 \mathrm{~min}$. The buffer medium (M20) had the same composition as M2 except for the sodium phosphate content which was $20.0 \mathrm{~g} / \mathrm{l}$. Additions to the media are noted in the text. Glucose was sterilized separately before addition. The inoculum consisted of spores. Growth and bacitracin production occurred in $500 \mathrm{ml}$ Erlenmeyer flasks incubated at $37^{\circ} \mathrm{C}$ at about 360 rev./min on a New Brunswick rotatory shaker (Model G-53).

Microbiological assay and detection of bacitracin. Bacitracin was determined by an agar diffusion method and detected by growth of Micrococcus flavus after thin-layer chromatography (t.1.c.) as described previously (Haavik \& Thomassen, 1973).

Growth. Bacterial growth was measured as extinction at $650 \mathrm{~nm}\left(E_{650}\right)$ in a Spectronic 20 spectrophotometer.

Preparation of inoculum. The bacteria were spread on the surface of agar plates (Difco, antibiotic medium No. I) and incubated at $37{ }^{\circ} \mathrm{C}$ for 7 days. The spores produced were washed off with sterile saline and treated with $0.1 \%$ lysozyme in order to destroy whole bacteria and debris. The spores were washed three times with sterile saline and finally diluted in saline to give an $E_{650}$ of $24^{\circ}$. The size of inoculum was $0.05 \mathrm{ml}$ of the spore suspension.

\section{RESULTS}

\section{Growth and bacitracin production in $\mathrm{M} 2$ medium}

The growth of Bacillus licheniformis ATCCI07I6 in medium M2 gave bacitracin titres of approx. I3 i.u./ml after $24 \mathrm{~h}$ incubation (Table I). Further incubation reduced the titre. The release of bacitracin from the bacteria closely paralleled growth, maximum titre of bacitracin being found in the culture fluid at about the same time as the culture entered the stationary phase. During all stages of growth significant amounts of bacitracin were detected by t.1.c. and subsequent overlaying with Micrococcus flavus. It appears that the bacitracin is formed as the organisms are actively dividing.

\section{Effect of glucose upon bacitracin formation}

By adding glucose to the M2 medium, bacitracin formation was retarded (Table 2). The more glucose added the later bacitracin was detected in the culture fluid, whereas growth was not influenced. 


\section{Table 1. Bacitracin production during growth in $M 2$ medium}

\begin{tabular}{|c|c|c|c|}
\hline $\begin{array}{l}\text { Time of } \\
\text { incubation } \\
\text { (h) }\end{array}$ & $\begin{array}{c}\text { Growth } \\
\left(E_{650}\right)\end{array}$ & $\begin{array}{l}\mathrm{pH} \text { of the } \\
\text { culture fluid }\end{array}$ & $\begin{array}{l}\text { Bacitracin in } \\
\text { culture fluid } \\
\text { (i.u./ml) }\end{array}$ \\
\hline 7 & 0.14 & $7 \cdot 37$ & $<0 . I^{*}$ \\
\hline 8 & 0.20 & $7 \cdot 48$ & $<0 . I^{*}$ \\
\hline 9 & 0.34 & $7 \cdot 58$ & $O \cdot I$ \\
\hline 10 & 0.64 & $7 \cdot 77$ & 0.4 \\
\hline I I & $\mathrm{I} \cdot \mathrm{IO}$ & $7 \cdot 90$ & 0.5 \\
\hline I 2 & $I \cdot 50$ & 8.05 & 0.6 \\
\hline 14 & 3.70 & $8 \cdot 28$ & 4.0 \\
\hline I 6 & 5.90 & $8 \cdot 35$ & $8 \cdot 4$ \\
\hline I 8 & $7 \cdot 40$ & $8 \cdot 47$ & $9 \cdot 8$ \\
\hline 20 & $8 \cdot 60$ & 8.65 & 10.4 \\
\hline 24 & 9.45 & 8.83 & I 2.5 \\
\hline 26 & 9.50 & 8.92 & $12 \cdot 0$ \\
\hline 28 & $8 \cdot 10$ & $9 \cdot 25$ & $7 \cdot 7$ \\
\hline
\end{tabular}

The maximum titre of bacitracin was also affected by glucose. When $0.5 \%$ glucose was added to the medium a maximum titre of about $20 \mathrm{i} . u$./ml was found (Table 2). This is a marked stimulation as compared with the 13 i.u./ml of bacitracin produced when glucose is absent (Table I). With higher concentrations of glucose in the medium bacitracin production fell.

\section{Effect of $\mathrm{CaCO}_{3}$}

Addition of glucose to the $\mathrm{M} 2$ medium led to a lowered $\mathrm{pH}$ of about 5.5 during the first hours of growth (Table 2). The more glucose added, the longer was the duration of the low $\mathrm{pH}$. This decrease in $\mathrm{pH}$ may reflect the accumulation of pyruvic acid and acetic acid formed from glucose (Halvorson, 1962).

$\mathrm{CaCO}_{3}(0.5 \%)$ in the $\mathrm{M} 2$ medium with $\mathrm{I} \cdot 0 \%$ glucose prevented both the fall in $\mathrm{pH}$ and the inhibition of the early bacitracin production by glucose (Table 3 ).

\section{Effect of phosphate buffer}

Growth of Bacillus licheniformis in the medium with increased phosphate (M20) gave bacitracin titres of about 19 i.u./ml after $28 \mathrm{~h}$ incubation. When $0.5 \%$ glucose was added to this medium a maximum titre of about $40 \mathrm{i} . \mathrm{u}$. bacitracin $/ \mathrm{ml}$ was found (Table 4 ).

Since glucose causes an early fall in $\mathrm{pH}$, the $\mathrm{pH}$ is lower during later stages of growth than in media without glucose (Tables I and 2). The $\mathrm{pH}$ of the M2O medium was reduced with $\mathrm{HCl}$ to see whether this lower $\mathrm{pH}$ could stimulate bacitracin production. When the initial $\mathrm{pH}$ was lowered to 6 , the $\mathrm{pH}$ of the culture during later stages of growth was found to be practically identical to that recorded when glucose was a constituent of the medium (Table 4). The lower $\mathrm{pH}$ values during later stages of growth gave approx. 40 i.u. bacitracin $/ \mathrm{ml}$, the same high bacitracin production as when glucose was added.

\section{Effect of $\mathrm{NaOH}$}

The $\mathrm{pH}$ of the $\mathrm{M} 20$ medium with initial $\mathrm{pH} 6$ reached about $7 \cdot 0$ after $16 \mathrm{~h}$. Adding $\mathrm{NaOH}$ to $\mathrm{pH} 8.5$ produced only 13.6 i.u. bacitracin $/ \mathrm{ml}$ in the culture fluid after an additional $4 \mathrm{~h}$, and about 16 i.u./ml after $10 \mathrm{~h}$. The final $\mathrm{pH}$ was 8.7 . The control culture (M20 medium with initial $\mathrm{pH}$ 6) produced $2 \mathrm{I}$ i.u. bacitracin $/ \mathrm{ml}$ and a $\mathrm{pH}$ of 7.3 after an additional $4 \mathrm{~h}$, and about 40 i.u./ml and a final $\mathrm{pH}$ of $8 \cdot \mathrm{I}$ after $10 \mathrm{~h}$ (a total of $26 \mathrm{~h}$ of incubation). 

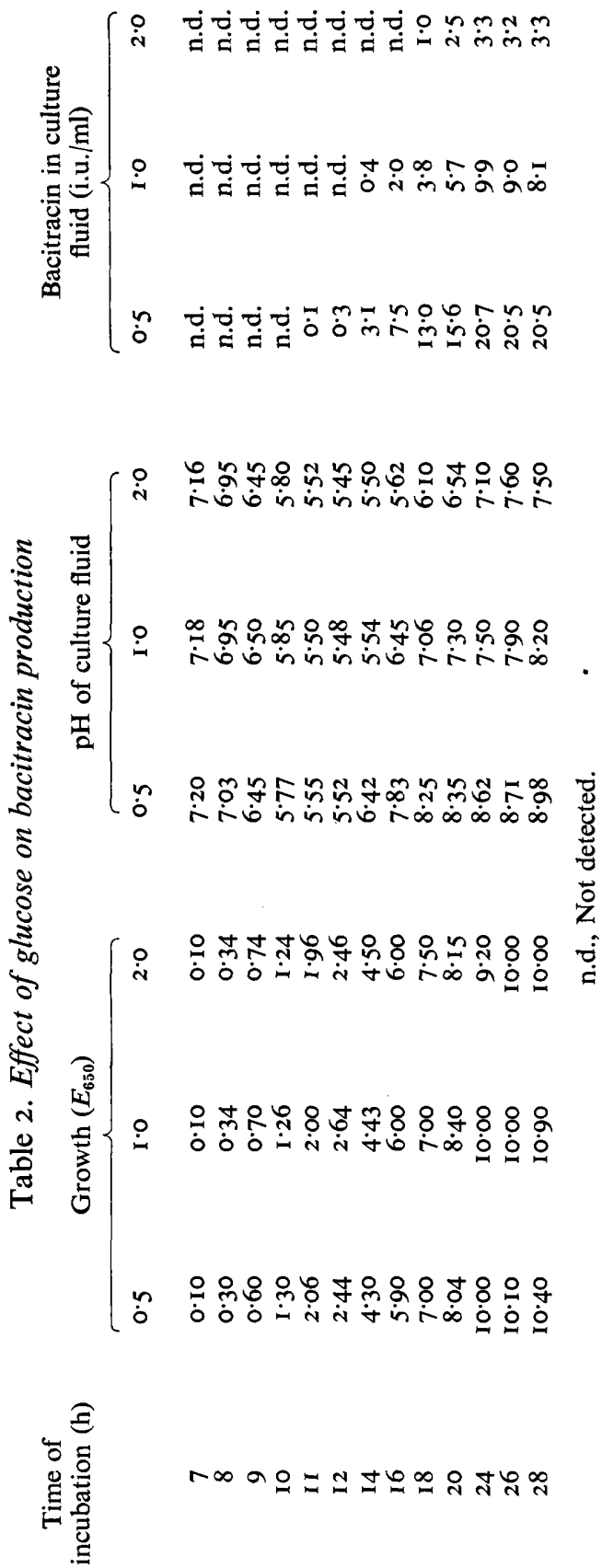


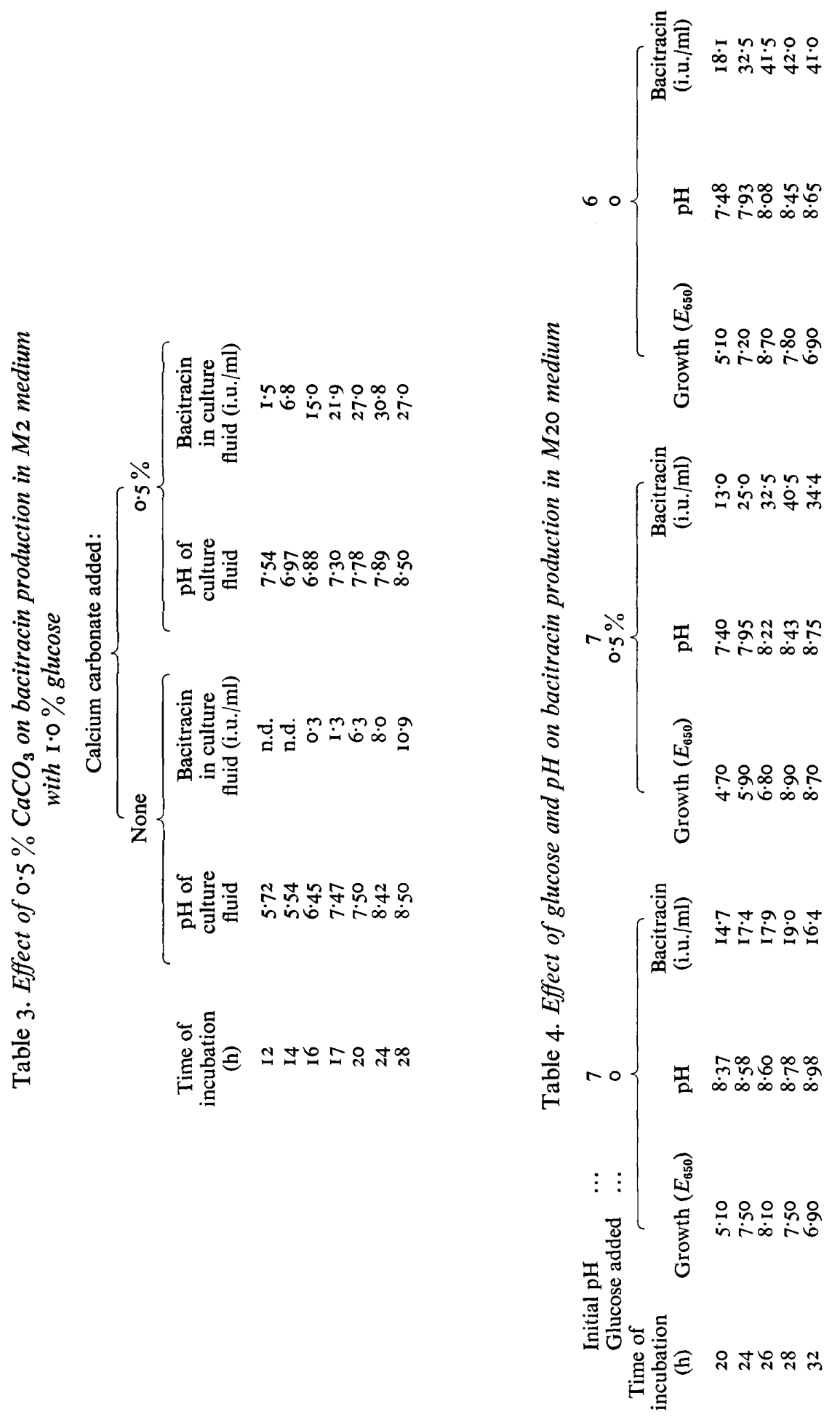




\section{DISCUSSION}

Bacitracin production by Bacillus licheniformis is greatly affected by the external $\mathrm{pH}$ of the bacteria. Simply by manipulating the buffer capacity of the medium the maximum titre increases from 13 i.u. bacitracin/ml in the M2 medium (Table I) to about 40 i.u. bacitracin/ $\mathrm{ml}$ in the M20 medium with an initial $\mathrm{pH}$ of 6 (Table 4). Both high and low pH values inhibit bacitracin synthesis. Our findings are in agreement with Snoke (196r) who reported a $\mathrm{pH}$ optimum of $8 \cdot 0$ for bacitracin formation by protoplasts of $B$. licheniformis.

Glucose metabolism stimulates bacitracin production, probably by reducing the $\mathrm{pH}$ during later stages of growth (Table 4). If too much glucose is added, a reduction of bacitracin titres is found (Table 2). Perhaps the long duration of the low $\mathrm{pH}$ period inhibits bacitracin production for most of the period of active growth, particularly as the postulated $\mathrm{pH}$ value of 8.0 for optimal production (Snoke, 196r) is not reached before growth is completed. The poor bacitracin titres obtained with too much glucose added ( $\mathrm{I} \%$ or more) can be avoided by adding $\mathrm{CaCO}_{3}$ which prevents the fall in $\mathrm{pH}$ (Table 3 ).

The inhibitory effect of glucose upon early bacitracin synthesis may explain the results of Bernlohr \& Novelli (1960; 1963) who reported that bacitracin production occurred after growth. A main constituent of their medium was glucose, and they also noted a fall in $\mathrm{pH}$ during the first period of incubation.

Snoke \& Cornell (1965) had already shown that the production of bacitracin by Bacillus licheniformis paralleled growth. However, their observation was described as 'puzzling and unusual' (Weinberg, 1967) and has not influenced the general view that peptide antibiotics are produced after growth. Their medium contained neither glucose nor other carbohydrates. According to our observations the early bacitracin production would not therefore be inhibited by unfavorable conditions.

Demain (1968) points out that many fermentations require carbon sources other than, or in addition to, glucose for optimal antibiotic production. Excellent carbon sources for antibiotic production are as a rule very slowly oxidized by the bacteria. However, slow feeding of glucose has in many cases eliminated the need for a slowly utilizable carbon source and Demain (1968) suggested that the production of many antibiotics, among them bacitracin, may be controlled by catabolite repression by glucose. We propose that this is not true for bacitracin since inhibition of its production by glucose can be prevented by neutralizing the culture fluid with $\mathrm{CaCO}_{3}$ (Table 3 ). It is more likely that the rapidly usable glucose inhibits antibiotic production because of its drastic influence upon the $\mathrm{pH}$ of the medium.

An initial fall in $\mathrm{pH}$ has also been reported in the production of penicillin, cephalosporin C, mycobacillin, polymyxins and nisin (Jarvis \& Johnson, 1947; Demain, I963; Banerjee et al. 1967; Paulus, 1967; Hurst \& Dring, I968). It is therefore tempting to propose that the frequently observed production of peptide antibiotics after growth may be $\mathrm{pH}$ dependent. Several peptide antibiotics may, like bacitracin, be produced during the whole period of active growth. It would therefore be of great interest to perform experiments which could explain the function of these peptide antibiotics in the dividing organism.

I thank Mr T. Høyland, Director of Research and Development, for his support of this work and Drs S. Thomassen and H. P. Throndsen for helpful criticism and valuable discussions in preparing the text. For excellent technical assistance I am very grateful to Mrs Eva Gustavsson. 


\section{REFERENCES}

Anker, H. S., Johnson, B. A., Goldberg, J. \& Meleney, F. L. (1948). Bacitracin: methods of production, concentration, and partial purification, with a summary of the chemical properties of crude bacitracin. Journal of Bacteriology 55, 249-255.

BanerJee, A. B., MaJumdar, S. K. \& Bose, S. K. (1967). Mycobacillin. In Antibiotics, vol. 2, pp. $271-275$. Edited by D. Gottlieb and P. D. Shaw. Berlin, Heidelberg and New York: Springer-Verlag.

Bernlohr, R. W. \& Novelli, G. D. (1960). Some characteristics of bacitracin production by Bacillus licheniformis. Archives of Biochemistry and Biophysics 87, 232-238.

Bernlohr, R. W. \& Novelli, G. D. (1963). Bacitracin biosynthesis and spore formation: the physiological role of an antibiotic. Archives of Biochemistry and Biophysics 103, 94-104.

Bu'Lock, J. D. (196I). Intermediary metabolism and antibiotic synthesis. Advances in Applied Microbiology 3, 293-342.

Demain, A. L. (1963). Synthesis of cephalosporin C by resting cells of Cephalosporium sp. Clinical Medicine 70, 2045-205I.

DEMAIN, A. L. (1968). Regulatory mechanisms and the industrial production of microbial metabolites. Lloydia 31, 395-4I8.

Gallo, M. \& KaTZ, E. (1972). Regulation of secondary metabolite biosynthesis: catabolite repression of phenoxazinone synthase and actinomycin formation by glucose. Journal of Bacteriology ro9, 659-667.

HAAVIK, H. I. \& Thomassen, S. (1973). A bacitracin-negative mutant of Bacillus licheniformis which is able to sporulate. Journal of General Microbiology 76, 45I-454.

Halvorson, H. (1962). Physiology of sporulation. In The Bacteria, vol. 4, pp. 223-264. Edited by I. C. Gunsalus and R. Y. Stanier. New York and London: Academic Press.

Hanson, R. S., Peterson, J. A. \& Yousten, A. A. (1970). Unique biochemical events in bacterial sporulation. Annual Review of Microbiology 24, 53-90.

Hickey, R. J. (1964). Bacitracin, its manufacture and uses. In Progress in Industrial Microbiology, vol. 5, pp. 93-I50. Edited by D. J. D. Hockenhull. London: Temple Press.

Hodgson, B. (1970). Possible roles for antibiotics and other biologically active peptides at specific stages during sporulation of Bacillaceae. Journal of Theoretical Biology 30, I I I-I 19.

HurST, A. (1969). Biosynthesis of polypeptide antibiotics. In The Bacterial Spore, pp. I67-182. Edited by G. W. Gould and A. Hurst. London and New York: Academic Press.

Hurst, A. \& Dring, G. J. (1968). The relation of the length of lag phase of growth to the synthesis of nisin and other basic proteins by Streptococcus lactis grown under different cultural conditions. Journal of General Microbiology 50, 383-390.

JARVIS, F. G. \& JoHnson, M. J. (I947). The role of the constituents of synthetic media for penicillin production. Journal of the American Chemical Society 69, 3010-3017.

JAYARAMAN, K. \& KENNAN, R. (1972). The role of polypeptide antibiotics on the bacterial differentation. Biochemical and Biophysical Research Communication 48, I235-I 239.

KatZ, E. (1968). Peptide antibiotics: proteins that never grew up? Lloydia 31, 364-394.

Katz, E. (197I). Biosynthesis of polypeptide antibiotics. Pure and Applied Chemistry 28, 55I-570.

Katz, E., Wise, M. \& Weissbach, H. (I965). Actinomycin biosynthesis. Differential effect of chloramphenicol on protein and peptide antibiotic synthesis. The Journal of Biological Chemistry 240, 3071-3078.

KurYlo-Borowska, Z. (1967). Edeine. In Antibiotics, vol. 2, pp. 342-352. Edited by D. Gottlieb and P. D. Shaw. Heidelberg and New York: Springer-Verlag.

Mach, B., Reich, E. \& TATum, E. L. (1963). Separation of the biosynthesis of the antibiotic polypeptide tyrocidine from protein biosynthesis. Proceedings of the National Academy of Sciences of the United States of America 50, 175-181.

Paulus, H. (I967). Polymyxins. In Antibiotics, vol. 2, pp. 254-267. Edited by D. Gottlieb and P. D. Shaw. Heidelberg and New York: Springer-Verlag.

SAdofF, H. L. (1972). Sporulation antibiotics of Bacillus species. In Spores, vol. 5, pp. I57-I66. Edited by H. C. Halvorson, R. Hanson and L. L. Campbell. Washington: American Society for Microbiology.

Sarkar, N. \& Paulus, H. (1972). Function of peptide antibiotics in sporulation. Nature New Biology 239 , 228-230.

Sermonti, G. (1969). Antibiotics and the microbial cell. In Genetics of Antibiotic-producing Microorganisms, pp. I-25. Edited by G. Sermonti. London, New York, Sydney and Toronto: John Wiley.

SNoke, J. E. (1960). Formation of bacitracin by washed cell suspensions of Bacillus licheniformis. Journal of Bacteriology 80, 552-557. 
SNOKE, J. E. (196r). Formation of bacitracin by protoplasts of Bacillus licheniformis. Journal of Bacteriology 81, 986-989.

SNoke, J. E. \& Cornell, N. (1965). Protoplast lysis and inhibition of growth of Bacillus licheniformis by bacitracin. Journal of Bacteriology 89, 415-420.

WeinberG, E. D. (1967). Bacitracin, gramicidin and tyrocidine. In Antibiotics, vol. 2, pp. 240-253. Edited by D. Gottlieb and P. D. Shaw. Heidelberg and New York: Springer-Verlag.

WEINBERG, E. D. (1970). Biosynthesis of secondary metabolites: roles of trace metals. Advances in Microbial Physiology 4, I-44.

Weinberg, E. D. (1971). Secondary metabolism: raison d'être. Perspectives in Biology and Medicine $\mathbf{1 4}$, 565-577.

WINNICK, R. E., LIS, H. \& WINNICK, T. (I96I). Biosynthesis of Gramicidin S. I. General characteristics of the process in growing cultures of Bacillus brevis. Biochimica et biophysica acta 49, 451-462.

WoODRUFF, H. B. (I966). The physiology of antibiotic production: the role of the producing organism. Symposia of the Society for General Microbiology 16, 22-46.

YoshidA, T. \& KATAGIRI, K. (1969). Biosynthesis of the quinoxaline antibiotic, triostin by Streptomyces s-2-2 IOL. Biochemistry 8, 2645-265I. 